Conference on Low-temperature Physics to be held in Toronto during August 29-September 3. Further information can be obtained from Dr. F. G. Brickwedde, College of Chemistry and Physics, Pennsylvania State University, Pennsylvania.

\section{The German Geological Association: Jubilee Meeting}

THE Geologische Vereinigung held its jubilee meeting at Würzburg during March 12-14 and it was attended by more than four hundred geologists. The theme considered was orogens. Some thirty authors contributed, their papers being grouped under the headings: time and matter in orogenesis, and structure and distribution of orogens. In the first part the concept of geosynclines was discussed and the sedimentation, metamorphism and the part played by magma within them enlarged upon. In the second, special structures within mountain chains of five continents were described and the differences between those near, or on, the surface and those existing at depth were contrasted. The principal award of the Association, the Steinmann Medal, was made to Prof. H. H. Read, emeritus professor of geology in the University of London, for his outstanding contributions to geological science.

\section{Helminthulogical Society of Washington Anni- versary}

THE Helminthological Society of Washington will observe its fiftieth anniversary on October 8. The scientific programme will be held in the University of Maryland, College Park, Maryland. A banquet will be held during the evening at the Naval Officers Club at Bethesda, Maryland. Dr. Chauncey D. Leake, president of the American Association for the Advancement of Science, will be the speaker at a banquet to be held on that day.

\section{Wool Textile Research Conference}

The second Quinquennial Wool Textile Conference is to be held in the United Kingdom during May 18-28. The conference, the theme of which is "Fibre Science", is to be arranged by the U.K. Textile Institute and is to be held at Harrogate. Participants from other countries include: Australia, Belgium, Canada, Germany, Japan, Netherlands, New Zealand, Norway, South Africa, Sweden, Switzerland and the United States. Further details can be obtained from the Textile Institute, 10 Blackfriars Street, Manchester 3.

\section{Summer Meeting of the Illuminating Engineering Society}

THE Illuminating Engineering Society is holding its biennial summer meeting at Harrogate during May 15-18. Three papers will be presented: "Progress in the Field of Electric Lamps", by H. G. Jenkins (General Electric Co., Ltd.); "Rationally Recommended Illumination Levels", by H. C. Weston; "Plastics, Yesterday, To-day and Tomorrow", by C. L. Child (Imperial Chemical Industries, Ltd.). Further information can be obtained from the Secretary, Illuminating Engineering Society, 32 Victoria Street, London, S.W.1.

\section{Announcements}

H.M. The Queen, who is Patron of the Royal Society, will open the tercentenary celebrations of the Society at a meting in the Royal Albert Hall on the afternoon of July 19 (see Nature, March 26. p. 879).

DR. D. H. Follets, keeper of the Department of Electrical Engineering and Communications in the Science Museum, South Kensington, has been appointed director of the Museum in succession to Dr. T. C. S. Morrison-Scott, who is succeeding Sir Gavin de Beer at the British Museum (Natural History) (see Nature, March 26, p. 888). Mr. D. Chilton has been appointed keeper of the Department of Electrical Engineering and Communications.

Mr. R. C. Palmer, deputy director of research to Griffin and George, Ltd., and associated companies. has been appointed director of research in succession to Dr. A. J. P. Martin, who wishes to concentrate in future primarily on fundamental research. Mr. Palmer was on the staff of the Wool Industries Research Association, Leeds, during 1937-51, after which he was appointed director of research of the South African Wool Industrial Research Institute.

Mr. LAwrence SutTon, formerly director of studies at Ashridge College, has been appointed education officer to the Institution of Works Managers, 196 Shaftesbury Avenue, London, W.C.2. As such, he will collaborate with technical colleges running the Institution's two-year training course leading to the certificate in works management, of which more than a hundred were awarded in 1959 .

Applications are invited for the Bowles Memorial Travel Scholarship. The object of the Scholarship is to enable the holder to travel abroad for the purpose of either collecting plants for introduction to British gardens or studying practical horticulture in other countries. Applicants must be of the male sex, not more than twenty-eight years of age on January 1, 1961 , and have some academic connexion with horticulture. Applications should reach the Secretary, Royal Horticultural Society, Vincent Square. London, S.W.1, by September 30 .

UNDER the title "Postgraduate Courses 1960-61" the Imperial College of Science and Technology has issued a booklet giving particulars of postgraduate courses available leading to a degree or diploma and of shorter postgraduate courses (mainly lectures) for which, under appropriate conditions, certificates are also given (pp. xii + 113. London: Imperial College of Science and Technology (University of London), 1960). Many of the courses have been accepted by the Department of Scientific and Industrial Research as suitable for the tenure of Advanced Course Studentships, and grants for the courses in agricultural chemistry and nematology are awarded by the Ministry of Agriculture, Fisheries and Food.

The seventh General Assembly of the International Union for Conservation of Nature and Natural Resources will be held during June 15-24 in Warsaw. The Assembly is to be held jointly with the eighth Technical Meeting; the final sessions will take place in Cracow. Further information can be obtained from the Secretariat of the International Union for Conservation of Nature, 31 rue Vautier, Brussels.

Erratum. In the communication entitled "Methods for the Evaluation of the Antibacterial Activity of Surface-Active Compounds" in Nature of April 9, p. 132, col. 2, line 47, for "fats" read "fate". The line now reads "The fate of microorganisms in dishwater was investigated..." 